\title{
NOVITATES GABONENSES 52. \\ A NEW VARIETY WITHIN THE SPOROBOLUS INDICUS COMPLEX (GRAMINEAE)
}

\author{
M.S.M. SOSEF$^{1} \&$ L. NGOK BANAK ${ }^{2}$
}

\begin{abstract}
SUMMARY
Within the polymorphic $S$. indicus complex a new variety, var. saxicola Sosef \& Ngok Banak, is being distinguished, based on its small habit, short and narrow leaves and especially its lax panicle with short primary branches.
\end{abstract}

Key words: Sporobolus, grasses, inselbergs, taxonomy, Africa, Gabon.

\section{INTRODUCTION}

In 2003, during fieldwork in eastern Gabon within the framework of a research project on Inselbergs (Ngok Banak, 2003), the second author collected material of a grass which the first author could not attribute to any known taxon. It appeared to belong to the Sporobolus indicus (L.) R.Br. complex (Clayton, 1965). The taxa distinguished within this highly polymorphic group are given the status of species by some authors (e.g., Clayton, 1965; Jovet \& Guédès, 1968; Clayton et al., 1974; Cope, 1999) whereas others regard them as mere varieties of a single species (Simon, 1982; Baaijens \& Veldkamp, 1991; Van der Zon, 1992; Sosef, 1999). Differences between the taxa within the complex are slight and intermediates occur on a regular basis.

After further study of the available literature, and consultation with another grass specialist, Dr. J.F. Veldkamp (Nationaal Herbarium Nederland, Universiteit Leiden branch), it was agreed that the material deserved new taxon status.

Because the spikelet structure of the new material is almost identical to that of Sporobolus indicus (L.) R.Br. var. pyramidalis (P. Beauv.) Veldk. (= S. pyramidalis P. Beauv.) and plant habit is vaguely similar to that of the $S$. jacquemontii Kunth-form belonging to the same variety, it was decided that in this particular case the attribution of the level of variety was more appropriate than that of distinct species. Besides that, the main features that distinguish it from this and other related taxa might be related to the extreme habitat in which the plants were growing (see Ecology below), which further supports our choice of the variety level.

The plants stand out because they form dense tussocks with very short and narrow leaves, possess almost leafless and short culms, and especially because of the very lax panicles with very short and distant primary branches.

1) Nationaal Herbarium Nederland, Wageningen University branch, Biosystematics Group, Wageningen University, Generaal Foulkesweg 37, 6703 BL Wageningen, The Netherlands.

2) Herbier National du Gabon, Iphametra, Cenarest, B.P. 1156, Libreville, Gabon. 

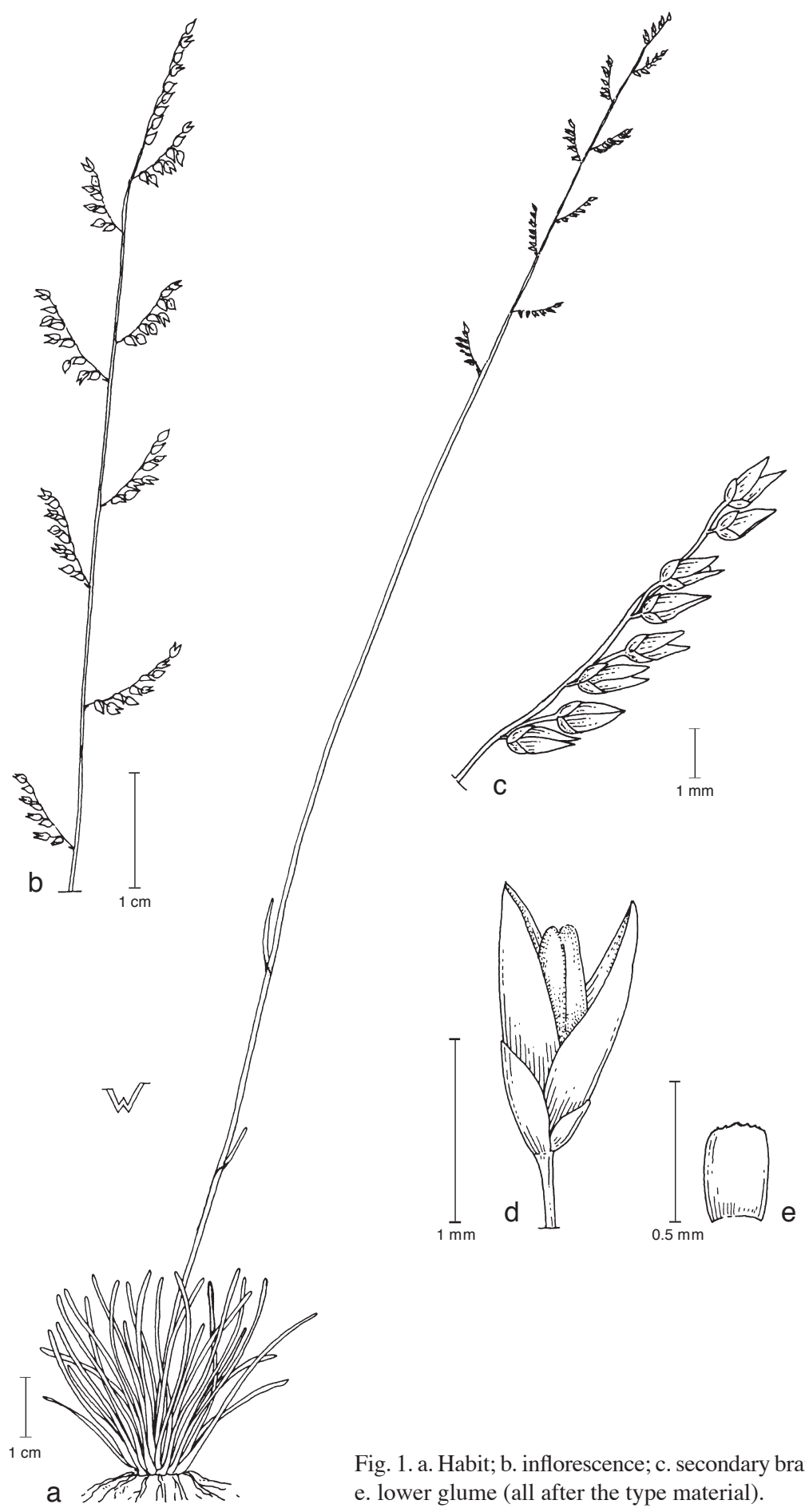

Fig. 1. a. Habit; b. inflorescence; c. secondary branch; d. spikelet; e. lower glume (all after the type material). 
Besides that, the seemingly paired spikelets represent a strange phenomenon. The pairs are composed of a sessile and a pedicelled spikelet, as is the rule in the tribe Andropogoneae. The same situation was observed in material belonging to the S. jacquemontii-form. This feature is believed to be caused by the fact that the secondary branches are reduced, leaving just the most basal sessile spikelet and a second spikelet sitting on top of the reduced secondary branch.

\section{DESCRIPTION}

Sporobolus indicus (L.) R.Br. var. saxicola Sosef \& Ngok Banak, var. nov. - Fig. 1

Sporoboli indici var. pyramidali similis, habitu minore, foliis brevioribus $(2-15 \mathrm{~cm})$ angustioribus $(0.7-2 \mathrm{~mm})$, panicula laxissima ramulis primariis brevissimis $(0.4-1.5 \mathrm{~cm})$ distantibus differt. - Typus: L. Ngok Banak, A. Moungazi \& P. Mbazza 1766 (holo WAG; iso LBV), Gabon, Ogooué-Ivindo, Mt Sassamongo, rocky plateau W of Sassamongo village, $0^{\circ} 49^{\prime} 71^{\prime \prime} \mathrm{N}, 13^{\circ} 28^{\prime} 06^{\prime \prime} \mathrm{E}, 485 \mathrm{~m}$ alt., prairie humide. Herbe de $0.20 \mathrm{~m}$ environ, inflorescence rouge violacée, 15 May 2003.

Perennial, caespitose, completely glabrous grass; culms erect, only $0.5-0.8 \mathrm{~mm}$ in diameter at the base, $12-33 \mathrm{~cm}$ long, striate, bearing only 1 or 2 reduced leaves. Leaves mostly basal; sheaths 3-20 mm long, striate; blades convolute, 2-15 cm long, 0.7-2 mm wide, with smooth margins; ligule a minute membranous rim of $0.2 \mathrm{~mm}$ set with short cilia. Panicle very lax, $2.5-13 \mathrm{~cm}$ long; primary branches solitary, quite distant, $0.4-1.5 \mathrm{~cm}$ long, with spikelets from the base. Spikelets generally in pairs, one sessile and one pedicelled, gaping, 1.4-1.6 mm long, brownish; lower glume obtuse, 0.4-0.5 mm long, about $1 / 3$ of the length of the spikelet, veinless; upper glume obtuse to acute, $0.5-0.8 \mathrm{~mm}$, up to half as long as the spikelet, indistinctly 1-veined; lemma acute, as long as the spikelet, 1-veined; palea similar to the lemma, 2-veined; anthers 3. Grain ellipsoid, c. $0.8 \mathrm{~mm}$ long.

Ecology - Sassamongo Mountain has, similar to the nearby Belinga and BokaBoka Mountains, base rock rich in iron giving rise to ferralitic soils (EDICEF, 1983). The type specimens were collected on a rocky plateau with shallow soils. The plants were growing in a depression that was regularly wet carrying a herbaceous vegetation dominated by Utricularia andogensis, Habenaria procera, Tricapelemma species, Heterotis rupicola and Xyris species.

\section{ACKNOWLEDGEMENTS}

We are grateful to Dr. J.F. Veldkamp (Nationaal Herbarium Nederland, Universiteit Leiden branch) for his valuable comments, assistance in locating relevant literature, and in providing the Latin diagnosis. The Small Grants program for Africa of the Wildlife Conservation Society and the Project Station de Recherche IRET/CIFOR Makokou, Ipassa provided financial support for the mission during which this material was collected. Mrs. Wil Wessel-Brand prepared the illustration.

\section{REFERENCES}

Baaijens, G.J. \& J.F. Veldkamp. 1991. Sporobolus (Gramineae) in Malesia. Blumea 35: 393-458. Clayton, W.D. 1965. Studies in the Gramineae: VI. Kew Bull. 19: 287-296. 
Clayton, W.D., S.M. Phillips \& S.A. Renvoize. 1974. Gramineae (Part 2). In: R.M. Polhill (ed.), Flora of Tropical East Africa: 177-449. Crown Agents for Oversea Governments and Administrations, London.

Cope, T. 1999. Eragrostideae Stapf. In: G.V. Pope (ed.), Flora Zambesiaca 10, 2: 15-202. Royal Botanic Gardens, Kew.

EDICEF. 1983. Géographie et cartographie du Gabon. EDICEF, Paris.

Jovet, P. \& M. Guédès. 1968. Le Sporobolus indicus (L.) R.Br. var. fertilis (Steud.) Jov. et Guéd. naturalisé en France, avec une revue du groupe du Sporobolus indicus dans le monde. Bull. Centr. Etudes Rech. Sci. [Biarritz] 7, 1: 47-75.

Ngok Banak, L. 2003. Etude de l'influence de la présence d'un Inselberg sur la forêt dense périphérique dans les Monts de Cristal (Inselberg de Milobo, Nord Ouest). In: Sebsebe Demissew, Ensermu Kelbessa \& S. Edwards (eds.), XVIIth AETFAT Congress, 21-26 September 2003. Abstracts: 71-72. Addis Ababa University Press.

Simon, B.K. 1982. Notes on Sporobolus in Australia. A.S.B.S. Newslett. 31: 16-19.

Sosef, M.S.M. 1999. Gramineae (Supplément). Flore du Gabon, vol. 5bis. Muséum National d'Histoire Naturelle, Paris.

Van der Zon, A.P. M. 1992. Graminées du Cameroun, vol. II, Flore. Wageningen Agric. Univ. Papers 92-1: 1-557. 